przedstawia krótki rys nurtów wychowawczo-politycznych, w dobie walki o kształt odrodzonej Polski.

Natomiast nad wkładem Barbary Żulińskiej do polskiej pedagogiki zastanawia się w swym tekście Andrzej Meissner, który w toku swych rozważań przybliża czytelnikowi postać autorki dzieła „Ku zmartwychwstaniu”, będącego monumentalnym, bo liczącym 650 stron kompendium wiedzy na temat prądów i kierunków w pedagogice XIX i pierwszej połowy XX wieku, ze szczególnym uwzględnieniem nurtu chrześcijańskiego w wychowaniu. Zulińska to postać ciekawa, a jej działalność na polu oświaty i nauki pozostawiła po sobie słlad, co niewatpliwie udowadnia czytelnikowi autor.

Z postacią Olgi Małkowskiej zaznajamia nas Edyta Głowacka-Sobiech. Przedstawia ona twórczynię "Dworku Cisowego" (Harcerskiej Szkoły Pracy w Sromowcach Wyżnych). Szkic prezentuje wiele informacji odnośnie powstawania oraz funkcjonowania tego nowatorskiego przedsięwzięcia, którego echa pobrzmiewają do dziś.

$\mathrm{Na}$ zakończenie książi przychodzi czytelnikowi spotkać się z Heleną Pelaczar i jej ,Stoneczną Górą Zdobywców". Adam Krzanowski w dużej mierze korzystajac ze słów samej bohaterki - cytujac jej pamiętniki - porusza wyobraźnie czytelnika, który w swoim umyśle widzi postać przepiękna, kochająca i do końca oddana dzieciom, szczególnie tym chorym i słabym. Już do ostatniego slowa czytelnik, pozostaje poruszony i zamyka książkę $\mathrm{z}$ głęboka refleksją i chwila zadumy.
Kobieta - to ona łączy wszystkie te artykuły, ale jest to kobieta niezwykła, bo o takich właśnie opowiada książka „Działalność kobiet polskich na gruncie oświaty i nauki". Poznajemy w niej wielkie działaczki, patriotki, niezłomne animatorki kultury, miłośniczki nauki, uczone, nauczycielki, wychowawczynie, matki... Książka oddana $w$ ręce czytelnika jest hołdem oddanym przez autorów nie tylko opisywanym osobowościom, ale wszystkim, które pełnią niezastapiona rolę kobiet, pokonując nieraz niejedne przeszkody, a to wszystko w imię drugiego człowieka. Ksiażka ta zasługuje na uwage nie tylko ze względu na jej informacyjno-biograficzny charakter, ale także dlatego, że przedstawia szerokie spektrum dziedzin i materii, wśród, których zaznaczyła się edukacyjna rola kobiet polskich. Ukazane zostało to na tle kontekstu historycznego i spoleczno-kulturowego, jest to niewatpliwie bardzo istotny element opracowania. Podsumowując pragniemy stwierdzić dużą wartość książki „Działalność kobiet polskich na polu oświaty i nauki", wyrażająca się zwłaszcza w jej faktograficzno-informacyjnym charakterze.

\section{Krzysztof Strzelecki}

1 „Działalność kobiet polskich na polu oswiaty i naukj" pod redakcja Wiesława Jamrożka i Doroty Żoładź-Strzelczyk, Wyd. ERUDITUS, Poznań 2003, s. 61.

\footnotetext{
2 Ibidem, s. 7.

3 Ibidem, s. 15.

4 Ibidem, s. 132.

5 Ibidem, s. 160.
}

\title{
Adam Fijałkowski, Puer eruditus. Idee edukacyjne Wincentego z Beauvais (ok. 1194-1264), Wydawnictwo Neriton, Warszawa 2001, ss. 225, sum., H.
}

Zainteresowanie epoka średniowiecza jest wśród historyków wychowania zaskakująco niewielkie, stąd cieszy ukazanie się na rynku monografii poświęconej analizie poglądów pedagogicznych jednego $\mathrm{z}$ francuskich encyklopedystów i teoretyków wychowania XIII w. Warszawski historyk Adam Fijalkowski już od kilku lat w trakcie różnych konferencji naukowych prezentował referaty omawiające różne aspekty twórczości Wincentego $\mathrm{z}$ Beauvais, uczonego zwiazanego z zakonem dominikanów, a co ciekawe, przebywającego jednak i tworzącego w cysterskim klasztorze w Royamount ${ }^{1}$. Prezentowana ksiażka jest zatem owocem wieloletnich badań.

Praca składa się z sześciu rozdzialów poprzedzonych wstępem, a zakończonych biblio- 
grafią oraz streszczeniami w języku angielskim i francuskim. Ksiażka opatrzona została ponadto indeksami i wkładka zawierajaca zdjęcia i fotokopie prac Wincentego z Beauvais.

„Dominikanin wśród cystersów” był autorem kilku tekstów, w tym Speculum maius - encyklopedii opisującej średniowieczna wiedzę o świecie. W literaturze historyczno-oświatowej zaistniał jako twórca traktatu pedagogicznego pt. De eruditione filiorum nobilium, zamieszczonego we fragmentach $\mathrm{w}$ Źródłach do historii wychowania pod tytutem Uzasadnienie kar cielesnych $w$ średniowieczu ${ }^{2}$, który, jak wykazuje Autor, ma się nijak do całości dzieła ${ }^{3}$.

Pierwszy rozdział poświęcony został Wincentemu jako czlowiekowi, omawia ponadto jego spuściznę pisarska. A. Fijałkowski przedstawił szeroko otoczenie społeczne, w którym dorastal a później pracował dominikański mnich, który pod wpływem renesansu XII w. podjął temat edukacji ludzi świeckich. Istotne i trafne wydaje sie przy tym zaakcentowanie bliskich związków Wincentego z królem Francji Ludwikiem IX Świętym i jego otoczeniem, w czasach kiedy ton wychowaniu przyszlych władców nadawało przysłowie: Rex illiteratus est quasi asinus coronatus. Autor poświęca sporo uwagi opiniom historiografii na temat Wincentego, w tym zawartych w podręcznikach historii wychowania - zwłaszcza niemieckich i polskich. Fijałkowski analizuje zwłaszcza syntezy Stanisława Kota, Stefana Woloszyna, którzy podchodzili bardzo krytycznie do epoki średniowiecza. Pamiętać przy tym należy, iż negatywny obraz twórczości Wincentego, głęboko zakorzeniony w polskiej literaturze przedmiotu, wynika m.in. z niefortunnego fragmentu traktatu cytowanego w Źródlach do historii wychowania.

W rozdziale drugim omówiona została obecność dzieł Wincentego z Beauvais na ziemiach polskich począwszy od epoki średniowiecza, a zwłaszcza dziejom rękopisu Speculum historiae, znajdującego się obecnie $w$ zbiorach Biblioteki Uniwersyteckiej we Wrocławiu. Autor zauważa, że dzieła Wincentego były obecne w Polsce już w XIV w., a ich posiadaczami byli zarówno duchowni (służyły one bowiem w pracy kaznodziejskiej - Wincenty nauczał przy pomocy przykladów), jak i świeccy, w tym profesorowie Uniwersytetu Krakowskiego - Stanisław ze Skal- bmierza, Pawel Wlodkowic, Mikołaj Kozlowski i inni. Dzieła Wincentego czytywali również kronikarze - Jan Długosz, Jan z Dąbrówki. Recepcja poglądów francuskiego dominikanina widoczna była już w twórczości Konrada z Byczyny. Sporo uwagi poświęca Autor również omówieniu stopnia zachowania dzieł Wincentego $w$ polskich zbiorach bibliotecznych, sygnalizując 108 inkunabułów. Ciekawe wydaje się spostrzeżenie, że w czasach nowożytnych zajmowano się głównie sporządzaniem wypisów z tekstów Wincentego.

Dalsze rozdziały poświęcono szczegółowym kwestiom zwiazanym z teoria pedagogiczna Wincentego z Beauvais, a więc: obrazowi idealnego nauczyciela, praktyce wychowania i wychowaniu idealnego wladcy świeckiego oraz potrzebom kształcenia świeckich elit państwowych. Rozdziały te umacniaja $w$ przekonaniu, iż Wincenty stworzył pierwsze w Europie średniowiecznej naukowe teksty poświęcone wyłącznie teorii i praktyce w wychowaniu - podręcznik dla nauczycieli i dla władcy świeckiego, w których zawarł doświadczenia płynące $\mathrm{z}$ własnej pracy naukowej i nauczycielskiej. Rozdzial III zatytułowano: „Teoria wychowania - koncepcja kształcenia i wychowania - cel i tradycje wychowania". A. Fijałkowski poddał tu analizie źródła teorii pedagogicznej Wincentego: teksty świętych Ambrożego, Hieronima, Augustyna, Tertuliana, a także filozofów starożytnych: Anneusza, Seneki, Boecjusza i uczonych średniowiecznych na czele z Hugonem od św. Wiktora, św. Anzelmem z Canterbury. Zwraca przy tym uwage, że ,jądrem" koncepcji wychowawczej Wincentego jest stwierdzenie Augustyna, że wychowanie nie musi być przyjemne. Nazywa on wychowanie ,uczeniem i skrzywianiem chłopców, oraz strzeżeniem ciał dziewcząt, dawaniem im dobrego przykładu" 4 . Autor omawia również koncepcję człowieka, opartą głównie na augustianiźmie a przepojoną pozytywnym spojrzeniem na dzieciństwo. Prezentuje poglady Wincentego na szerokim tle intelektualnym epoki, umiejscawiając swego bohatera wśród najwybitniejszych umysłów Francji i Anglii XIII w. Cechowaly Wincentego nowatorskie spostrzeżenia: wiedza oparta na realiach życia, prezentowana w przyjemny sposób, nie zaniedbywal jednak spraw karności, uważając, że najlepszym środkiem wychowawczym jest pokora. W trosce o moralność pragnął Wincenty 
oddzielnego wychowywania dziewcząt $\mathrm{i}$ chłopców.

W rozdziale kolejnym A. Fijałkowski kreśli obraz idealnego nauczyciela, podkreślając sceptyczny stosunek Wincentego do wychowawczej roli rodziców. Wynikal on zapewne $z$ faktu, że praktyka edukacyjna tamtych czasów przewidywała posłanie dziecka do szkoły klasztornej lub miejskiej. Idealny nauczyciel, zdaniem Wincentego, powinien być cichy, pokorny i wewnętrznie zdyscyplinowany, ale zarazem dbajacy o wzbudzanie zainteresowania wśród uczniów - czynnych odbiorców treści dydaktycznych i wychowawczych przekazywanych przez nauczyciela. Porównując opisane przez Wincentego metody pracy nauczycielskiej z realiami średniowiecznego nauczania Autor wykazuje dobra orientacje w literaturze przedmiotu - zarówno polskiej, jak i angloi niemieckojęzycznej. Jego wywody sa rzetelnie udokumentowane w materiale źródłowym.

Rozdział $\mathrm{V}$ poświęcono analizie praktyki wychowawczej i mechanizmom pracy intelektualnej. Fijałkowski podkreśla szerokość zainteresowań Wincentego praktyka wychowawcza - również w sferze seksualnej, w tym plodnościa, stosunkami płciowymi itp. Konsekwencja tego byly również rozważania dotyczące przebiegu ciaży, porodu, opieki nad małym dzieckiem, wychowania w wieku dziecięcym i mlodzieńczym. Autor zauważa, że Wincenty zasadniczo pochwalał życie w celibacie, uważając małżeństwo za antidotum na pożądliwość seksualna. Wychowanie kobiet i mężczyzn w teorii pedagogicznej Wincentego z Beauvais różnią się znacząco: o ile w wychowaniu mężczyzn prym wiedzie wiedza i mądrość o tyle wychowanie dziewcząt skierowane jest ku kształtowaniu moralności, a nie intelektu. Wypadnie zauważyć tu brak nowatorstwa - wzorce wychowawcze opisane przez Wincentego sa bowiem odbiciem utrwalonych wówczas sadów w tej materii. Interesująca jest podjęta przez Autora próba odpowiedzi na pytanie, czy wzorce te sa konwencja literacka czy rzeczywistością wychowawcza, zakoníczona konkluzją o absolutnym ignorowaniu przez Wincentego realiów życia dworskiego.

Rozdział VI jest podsumowaniem treści dzieł Wincentego $\mathrm{z}$ Beauvais związanych $\mathrm{z}$ wychowaniem władcy świeckiego. Autor nie ograniczył się przy tym do nakreślenia jedynie programu nau- czania (króla powinna oczywiście cechować rzetelna wiedza), przedstawiajac cały szereg działań zmierzających do osiagnięcia ideału: władcy przewyższającego poddanych mądrością, sprawiedliwego, pokomego i dobrego. Już w młodości przyszły król powinien otaczać się ludźmi wiernymi, o dobrych obyczajach, ponieważ z tych osób wywodzić się powinni jego doradcy.

W zakończeniu Autor stwierdza, że wychowanie $w$ ujęciu Wincentego $z$ Beauvais nie jest zwartym systemem pedagogicznym, dodajac, iż brakuje w jego tekstach jasnej i samodzielnej koncepcji człowieka a układ nauk nakierowany jest na teologię. Ksztalcenie łączył Wincenty z surowym wychowaniem moralnym. Istotna wartością w dziełach Wincentego jest natomiast stworzenie spójnego obrazu idealnego nauczyciela, metod jego pracy z uczniem. A. Fijałkowski konkluduje myssla, że Wincenty stworzył najpełniejsza teoretyczna panorame problematyki wychowawczej w dotychczasowej teoretycznej literaturze sredniowiecznej.

Wartość pracy podnosi indeks osobowy i stosunkowo obszema bibliografia. Podkreślenia wymaga znaczący w niej udział materiałów źródłowych. Swe wywody A. Fijałkowski rzetelnie udokumentował bowiem bogactwem źródeł rękopiśmiennych, pochodzacych z bibliotek Paryża, Berlina, Brukseli, Krakowa i Wrocławia, jak i źródeł drukowanych. Co oczywiste Autor zna wszystkie wydania dzieł Wincentego z Beauvais, posłużył się również imponująca spuścizna pisarska Ojców Kościoła i uczonych średniowiecznych. Analizy tekstów Wincentego, porównania z dzielami wybitnych uczonych ówczesnej Europy prowadzone sa w klarowny sposób. Tok wykładu jest jasny i klarownie przedstawiajacy rozumowanie Autora, który swe sady opiera na nie budzącym watpliwości metodologicznych kwestionariuszu badawczym oraz na znajomości europejskiej i polskiej literatury przedmiotu. Warto podkreślić, że A. Fijalkowski czuje się swobodnie zarówno w literaturze pedagogicznej, jak i historycznej, przedstawiając szerokie spektrum czynników wpływajacych na sposób widzenia świata przez uczonego dominikanina.

Praca została starannie przygotowana pod względem edytorskim, w zasadzie pozbawiona jest poważniejszych usterek czy błędów. Wśród nielicznych dostrzeżonych usterek zasygnalizo- 
wać można umieszczenie w opracowanej według klucza alfabetycznego bibliografii Mistrza Wincentego tzw. Kadłubka po Stanisławie ze Skalbmierza (s. 197). Zaskakuje ponadto stosunkowo mały udział opracowań francuskojęzycznych w obszernej bibliografii. Uwagi powyższe maja jednak charakter „kronikarski” i w niczym nie umniejszaja wartości książki. Czytelnik otrzymuje bowiem w pracy A. Fijałkowskiego cenna i wartościową analizę średnjowiecznej myśli pedagogicznej.

\section{Krzysztof Ratajczak}

1 Np.: A. Fijałkowski, Wychowanie kobiet $w$ sivietle pism Wincentego z Beauvais ( $\dagger$ 1264), w: Partnerka, matka, opiekunka. Status kobiety w starożytności $i$ średniowieczu, red. J. Jundzill, Bydgoszcz 1999, s. 282 -296; tenże, Wincenty z Beauvais (ok. 1194-1264) w Royamount - dominikanin wśród cystersów, w: Cystersi w spoteczeństwie Europy Srodkowej. Materiaty z konferencji naukowej odbytej w klasztorze oo. Cystersów w Krakowie Mogile z okazji 900 rocznicy powstania Zakonu Ojców Cystersów. Poznań-Kraków-Mogila 5 - 10 października 1998, red. A. M. Wyrwa, J. Dobosz, Poznań 2000, s. $782-798$.

Uzasadnienie kar cielesnych w średniowieczu, w: Źródta do historii wychowania (Wyborr), Wybral i objaśnil S. Kot, cz. I, Warszawa 1929, s. 119-122 oraz pod tym samym tytulem w: Źródla do dziejów wychowania i myśli pedagogicznej, t. 1: Od wychowania pierwotnego do końca XVIII stulecia, wybór i opracowanie S. Wołoszyn, wyd. Il zmienione, Kielce 1995, s. 160-164.

A. Fijalkowski, Puer eruditus. Idee edukacyjne Wincentego z Beauvais (ok. 1194-1264), Warszawa 2001 , s. 64 i nn.

Tamże, s. 90

\section{Historia, społeczeństwo, wychowanie. Księga pamiątkowa dedy- kowana Profesorowi Józefowi Miąso, pod red. K. Bartnickiej, Pułtusk - Warszawa 2004, ss. 548}

Wyższa Szkoła Humanistyczna im. Aleksandara Gieysztora w Pułtusku oraz Instytut Historii Nauki Polskiej Akademii Nauk wydały w 2004 roku pracę Historia, spoteczeństwo, wychowanie. Została ona zadedykowana Profesorowi Józefowi Miąso, jednej z najbardziej zasłużonych postaci w polskiej historii wychowania. Do jej powstania przyczynili się nieomal wszyscy najważniejsi badacze tej dyscypliny.

Prezentowana pracę otwiera artykuł Kaliny Bartnickiej zatytułowany Profesor Józef Miaso - historyk wychowania, oświaty, nauki. Uczony, mistrz, przyjaciel i kolega. Ukazuje on sylwetkę Jubilata i jego dość skomplikowaną drogę edukacyjna, bo jak napisal on sam o sobie: Poczynajac od 6 roku zycia, chodzilem do dwóch szkót podstawowych, jednej doksztatcajacej $i$ trzech szkót średnich. Studiowatem $w$ dwóch uniwersytetach, mialem dwóch mistrzów naukowych, których inspiracjom intelektualnym i zwyklej ludzkiej zyczliwości zawdzięczam bardzo wiele 1 . K. Bartnickiej ponadto udało się przedstawić Józefa Miaso jako niezwykłego człowieka, bo Jego biografia jest $i$ wyjatkowa $i$ typowa zarazem, jak wiele zyciorysów Polaków tego pokolenia, którym los przynosit wielkie zagrozienia ale takze wielkie zyciowe szanse ${ }^{2}$ Część wstępna, ,jubileuszowa", pracy uzupełnia Bibliografia prac Józefa Miaso za lata 1958 - 2003, która pracowicie zestawiła Ewelina Tylińska.

Praca składa się z czterech części. Pierwsza z nich nosi tytuł Tradycja uniwersytecka i składa się nań dziesięć artykułów. Autorka pierwszego (Upadek uniwersytetów we Francji w XVIII w.) jest K. Bartnicka. Przedstawia ona tradycję, sięgająca nieomal sześciuset lat, kształcenia uniwersyteckiego we Francji i wskazuje na główne przyczyny jej upadku: rozdźwięk między programami nauczania (anachronicznymi i nieużytecznymi) a potrzebami społeczeństwa, niechęć do uniwersytetów niektórych środowisk (np.: ówczesnych filozofów, chociażby D. Diderota), wiązanie tychże instytucji z feudalnym porządkiem społecznym. Były to przyczyny na tyle glębokie, jak dowodzi K. Bartnicka, że Francuzi zechcieli wskrzesić idee uniwersyteckie dopiero po stu latach (1893 r.).

Kolejnym autorem omawianego tomu jest krakowski badacz, Julian Dybiec. Jego artykuł dotyczy współpracy między uniwersytetami od czasów średniowiecznych do najnowszych (XX 